\title{
ПЕРСПЕКТИВИ ДОСЛІДЖЕННЯ КРИСТАЛОГЕНЕЗУ РОТОВОЇ РІДИНИ В ДОКАЗОВІЙ ОРТОДОНТІЇ
}

\author{
О. П. Мінцер ${ }^{1}$, Ю. В. Ткаченко ${ }^{2}$ Р. Б. Слободской ${ }^{3}$, О. С. Литвиненко ${ }^{3}$ \\ Національна медична академія післядипломної освіти імені П. Л. Шупика мОз України ${ }^{1}$ \\ Харківський національний медичний університет ${ }^{2}$ \\ Харківський національний університет радіоелектроніки ${ }^{3}$
}

В статті наведено аналіз історичного розвитку напрямку салівадіагностики - мікрокристализації ротової рідини. Представлені результати власних досліджень мікрокристалограм, алгоритм дослідження фррактальних структур основного шару фацій слини. Визначені чіткі кількісні показники дендритів, що планується використовувати в подальшій розробці пакетів програмного забезпечення для об'єктивізації аналізу мікрокристализації слини в нормі та при патології.

Ключові слова: стоматологія, ротова рідина, кристалогенез, фрактальні структури.

\section{ПЕРСПЕКТИВЫ ИССЛЕДОВАНИЯ КРИСТАЛЛОГЕНЕЗА РОТОВОЙ ЖИДКОСТИ В ДОКАЗАТЕЛЬНОЙ ОРТОДОНТИИ}

\author{
О. П. Минцер ${ }^{1}$, Ю. В. Ткаченко ${ }^{2}$ Р. Б. Слободской ${ }^{3}$, Литвиненко \\ Национальная медицинская академия последипломного образования \\ имени П. Л. Шупика МЗ Украины ${ }^{1}$ \\ Харьковский национальный медицинский университет ${ }^{2}$ \\ Харьковский национальный университет радиоэлектроники ${ }^{3}$
}

\begin{abstract}
В статье проводится анализ исторического развития направления саливадиагностики - микрокристаллизации ротовой жидкости. Представлены результаты собственных исследований микрокристаллограмм, алгоритм изучения фрактальных структур основного слоя фаций слюны. Выделены чёткие количественные показатели дендритов, которые планируется использовать в дальнейшей разработке пакетов программного обеспечения для объективизации анализа микрокристаллизации слюны в норме и при патологии.
\end{abstract}

Ключевые слова: стоматология, ротовая жидкость, кристаллогенез, фрактальные структуры.

\section{PROSPECTS OF THE RESEARCH OF CRYSTAL GENESIS OF ASSORTED SALIVA IN EVIDENTIAL ORTHODONTICS}

\author{
O. P. Mintser ${ }^{1}$, Yu.V. Tkachenko², R. B. Slobodskoy ${ }^{3}$, O. S. Lytvynenko ${ }^{3}$ \\ National Medical Academy of Post-Graduate Education by P. L. Shupyk \\ of the Ministry of Public Health of Ukraine ${ }^{1}$ \\ Kharkiv National Medical University ${ }^{2}$ \\ Kharkiv National University of Radioelectronics ${ }^{3}$
}

\begin{abstract}
The article provides a historic overview of research of micro-crystallization of saliva in complex diagnostics of dental diseases. Proceeding from results of their own and borrowed research, the authors demonstrate the principal qualitative parameters of comprehensive characteristics of fractal structures in the main layer of saliva facies. The article offers the algorithm of their evaluation and marks prospective trends in using software packages for objective qualitative assessment of fractals of micro-crystallograms of saliva in the case of norm or dental pathology.
\end{abstract}

Key words: dentistry, assorted saliva, crystal genesis, fractal structures.

Вступ. У діагностиці стоматологічних захворювань в останні 30 років застосовується кристалографічний метод дослідження ротової рідини (РP) [1]. Характер малюнка мікрокристалограм (МКГ) визначається балансом органічних і неорганічних компонентів, основними фізико-хімічними ії властивостями. Склад

( ) О. П. Мінцер, Ю. В. Ткаченко, Р. Б. Слободской, О. С. Литвиненко 
слини, відображений на МКГ, характеризує психоемоційний [11] і функціональний стани організму [7], рівень обмінних процесів [14], ступінь тяжкості запальних процесів [13] і структурно-функціональні властивості емалі, тобто резистентність до карієсу [10].

Головними перевагами МКГ РР є неінвазивність, простота виконання, доступність [8]. Теоретичною основою можливості використання аналізу МКГ РР $\epsilon$ положення про здатність різних біосубстратів до кристалоутворення [12].

На сучасному етапі розвитку стоматологічної науки при діагностиці захворювань щелепно-лицевої ділянки й обгрунтуванні раціональної терапії широко використовуються методи доказової медицини [5 ]. Відповідно до них, актуальним $є$ вивчення динаміки вчень про кристалогенез фацій слини з метою вироблення чітких кількісних параметрів оцінки фрактальних структур для подальшої автоматизації аналізу МКГ РР.

Перші дослідження КГ показали, що на предметному склі після висушування краплі РР залишається осад, що має різну мікрокристалічну будову, залежну від стану організму та порожнини рота. Результати вивчення виділених типів мікрокристалізації характеризують ремінералізуючу здатність слини [4].

Далі були уточнені основні типи мікрокристалізації (МК) ротової рідини [9]. При першому типі МК відзначалися великі подовжені кристалопризматичні структури, правильно зрощені між собою з утворенням "хвоща" або "папороті" (5 балів).

При другому типі МК фрактальні (деревоподібні) структури з'єднуються в довільному порядку (4 бали). До третього типу віднесено малюнок кристалізації за умови, що в центрі видно окремі кристали зірчастої форми, по периферії збережені укрупнені деревоподібні кристали (3 бали). При четвертому типі МК зустрічаються окремі кристали у вигляді лозини або гілочки, розташовані по усьому полю (2 бали).

У п'ятому типі по всій площі краплі відзначається велика кількість кристалічних структур зірчастої, округлої і неправильної форми (1 бал). У разі повної відсутності кристалів в полі зору (0 балів) малюнок МКГ РР може бути віднесений до шостого типу.
Описані результати експериментально-клінічних досліджень, в ході яких встановлено, що у осіб з карієсрезистентною емаллю переважають 1 і 2 типи МК, i, навпаки, при високій інтенсивності каріозного процесу у більшості випадків зустрічається МК 4 і 5 типів.

При вдосконаленні КГ методу дослідження РР описовому аналізу піддалися усі складові малюнка МКГ: не лише фрактальні структури, але і окремі кристали, аморфна речовина. Інтерпретація кристалоскопічних компонентів виконувалася із застосуванням спеціалізованої таблиці аморфних і кристалічних структур, додаткових критеріїв.

Так, в периферійній зоні фацій слини в нормі спостерігаються переважання фігур типу "хрест" i "призма". Дендритна картина середньої зони представлена лінійчастими утвореннями, структурами типу "хвощ", "папороть" та ін. Реєструється зменшення розмірів аморфних тіл, зміна налипання на них великих кристалів на відтиснення від останніх [6].

Як вже згадувалося вище, 3 метою отримання кількісної оцінки фрактальних структур основного шару фацій змішаної слини робляться спроби використання існуючих пакетів програмного забезпечення для обробки графічних зображень (Adobe Photoshop 6.0 i PhotoDraw 2000, STATGRAPHICS Plus 5.0.), американських програм Hesperus (Am Lab.USA v.3.0 beta). Проте при використанні стандартних програм опис параметрів дендритних структур має суб'єктивний характер [2], а при використанні спеціалізованих програм виникає проблема дотримання авторських прав, що звужує круг користувачів [3]. У зв'язку з цим видається доцільним створення спеціалізованого програмного комплексу для автоматизованої обробки зображень, який дозволяв би отримати кількісні характеристики фракталів основного шару.

Отже, пошук шляхів об'єктивізації оцінки зображень, отриманих при дослідженні кристалізації слини, є актуальним. На наш погляд, для повної кількісної характеристики мікрокристалів необхідно розробити алгоритм дослідження мікрокристалограм: на малому збільшенні (х 40) вибрати основний шар фації (рис. 1); виділити фрактал; визначитися із загальною
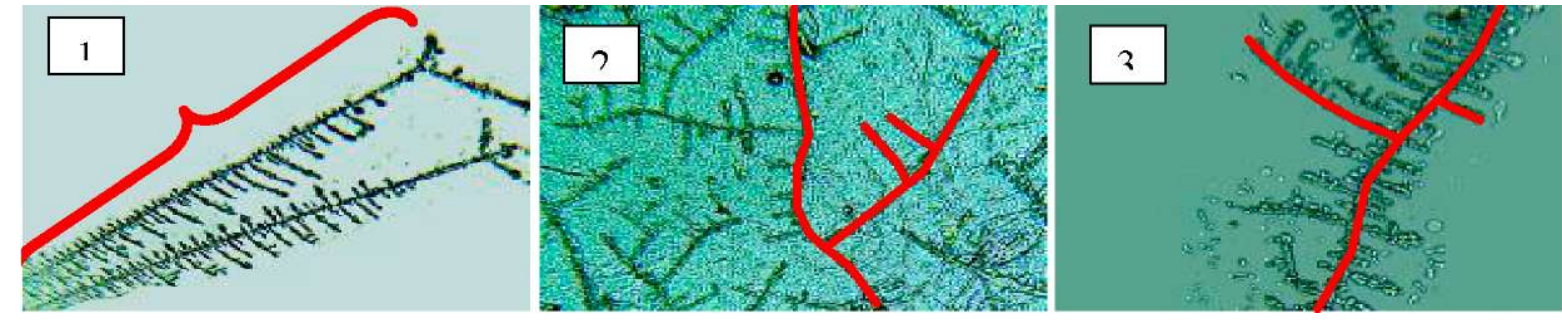

Puc. 1. Параметри дендриту, досліджувані на середньому збільшенні: 1) довжина кристала до місця розгалуження, 2) односторонні галуження, 3) двосторонні галуження. 
картиною зображення (форма фракталів, кількість органічних вкраплень). На середньому збільшенні (х 100) досліджувати виділений кристал (рис. 2), відношення периметра дендриту до його площі (рис. 3), міри кривизни основного стовбура, число поколінь галужень (1-го, 2-го та ін. порядку), частоту галужень, кут галужень.
На великому збільшенні (х 400) слід досліджувати форму закінчення (верхівки галуження - гостра або округла), ширину основного стовбура, безперервність основного стовбура. Багато вищеперелічених досліджень піддаються автоматизації, що створює передумови для написання спеціального програмного комплексу.

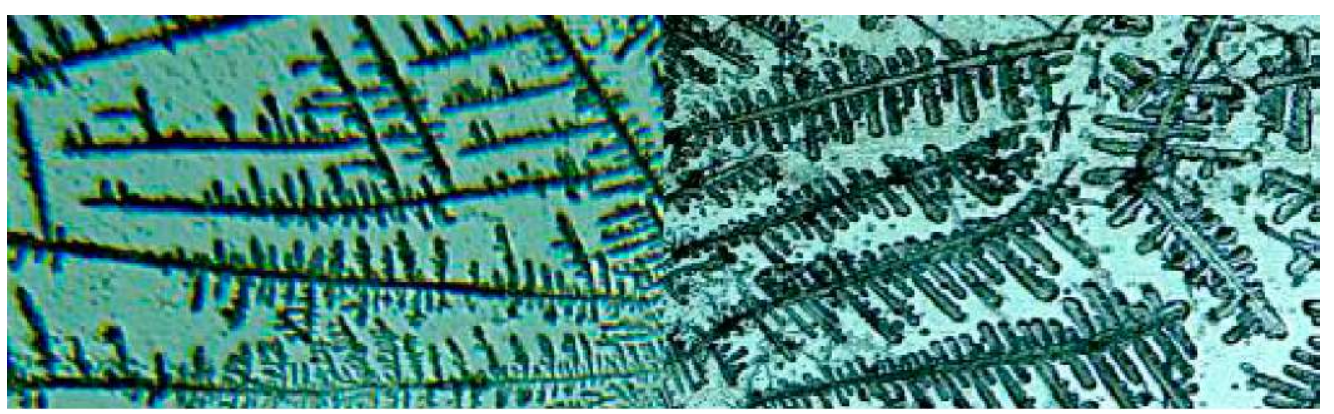

Puc. 2. Визначення співвідношення периметра кристала до його площі.

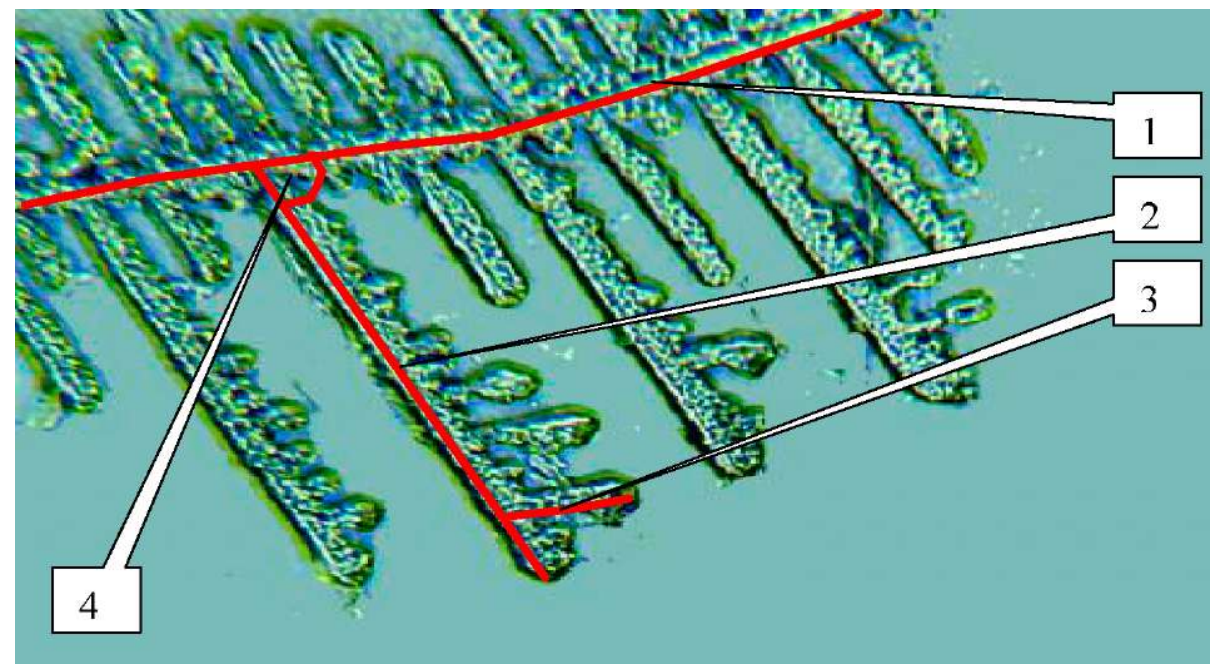

Puc. 3. Дослідження галужень основного стовбура: 1) основний стовбур, 2) галуження 1-го порядку, 3) галуження 2-го порядку, 4) кут галужень.

Висновки. 1. КГ методи дослідження здатні нести не лише діагностичні функції, але і служити чутливим індикатором функціонального стану організму людини в нормі і при патології. 2. КГ РР може розглядатися як досить простий, економічний, неінвазивний та інформа- тивний спосіб тестування стану організму в цілому і зубощелепної системи зокрема. 3. Актуальною є розробка систем аналізу зображень МКГ РР з використанням комп'ютерних технологій для доказового визначення кількісних характеристик фрактальних структур.

\section{Література}

1. Барер Г. М. Кристаллографический метод изучения слюны / Г. М. Барер, А. Б. Денисов. - М. : ВУНМЦ Росздрава, 2008. - 239 c.

2. Денисов А. Б. Алгоритм оценки кристаллических фигур, полученных при высушивании смешанной слюны / А. Б. Денисов // Бюллетень экспериментальной биологии и медицины. - 2004. - Т. 136, № 7. - С. 37-40.

3. Гайфулина В. Р. Микрокристаллизация ротовой жидкости у разных групп пациентов и её компьютерный анализ

/ В. Р. Гайфулина // Сборник научных студенческих работ «Студенты БГМУ - медицинской науке и здравоохранению Беларуси». - Минск : БГМУ, 2009. - С. 15 -16

4. Леус П. А. Клинико -экспериментальное исследование патогенеза, патогенетической консервативной терапии и профилактики кариеса зубов : автореф. дис. на соискание научной степени д-ра мед. наук / П. А. Леус. - Москва, 1977. - 30 c.

5. Леус П. А. Доказательная стоматология как основа про- 
грамм профилактики кариеса зубов у детей / П. А. Леус // Стоматология детского возраста и профилактика. - 2008. T. 7, № 2. - C. 3-11.

6. Мартусевич А. К. К раскрытию индикаторной роли кристаллографических методов исследования / А. К. Мартусевич// Естествознание и гуманизм. - 2005. - Т. 2, Вып. 3. C. $24-27$.

7. Мартусевич А. К. Поведение биологических жидкостей и функциональный статус организма человека / А. К. Мартусевич // Известия высших учебных заведений. Поволжский регион. - 2007. - № 2. - С. 24 - 30.

8. Постникова И. В. Перспективы применения комплексного кристаллографического исследования биологических жидкостей / И. В. Постникова // Успехи естествознания. 2007. - № 6. - С. 91 - 92.

9. Сайфулина Г. М. Оценка микрокристаллизации слюны у детей при кариесогенной ситуации в полости рта / Г. М. Сайфулина, А. Р. Поздеев, В. В. Гунчев // Метод. рекоменд. для субординаторов и врачей-интернов. - Казань, 1992. - 37 с.

10. Смоляр Н. И. Профилактика очаговой деминерализа- ции при различном состоянии структурно-функциональной резистентности эмали на этапах лечения несъёмной ортодонтической аппаратурой / Н. И. Смоляр, М. С. Дрогомирецкая // Современная стоматология. - 2002. - № 4 (20). - С. 48-51.

11. Уразаева Ф. Х. Пути изучения психофизиологических особенностей состава и свойств слюны / Ф. Х. Уразаева, К. Ф. Уразаев, М. В. Ларина // Современные наукоемкие технологии. - 2005. - № 3 - С. 44-45

12. Шабалин В. Н. Морфология биологических жидкостей человека / В. Н. Шабалин, С. Н. Шатохина. - М. : Хризопpa3, 2001. - $304 \mathrm{c}$.

13. Связь между активностью свободно-радикального окисления и характером структуропостроения биологической жидкости / Щербатюк Т. Г., Потехина Ю. П., Кулакова К. В. [и др.] // НМЖ (Нижегородский медицинский журнал). 2006. - №8. - C. 9 - 14.

Stephen Barrett, M.D. Herbal Crystallization Analysis. http:// www.quackwatch.org/01QuackeryRelatedTopics/Tests/ hca.html. 